\section{Australia plays hard to get}

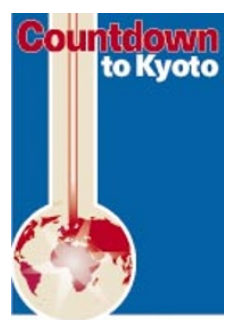

[SYDNEY] The Australian government, squeezed between the country's mining industry and the international community, has announced measures to curb greenhouse gas emissions at a cost of A\$180 million (US\$124 million) over four years. But the planned shift towards renewable energy aims not to cut emissions or even to level them out, but to reduce from 28 per cent to 18 per cent the anticipated increase over 1990 levels by the year 2010 - a reduction of 39 million tonnes of carbon a year.

Supported by Australia's large exporters of coal and minerals, the Prime Minister, John Howard, has refused to yield to pressure from other countries to accept mandatory emissions limits in the run-up to the Kyoto meeting next month. He claims the European plan for reducing emissions by 15 per cent by 2010 would cost Australia 90,000 jobs.

Howard told parliament that Australia wants to retain "bargaining chips" and will not "telegraph its negotiating position".

But the planned measures have not had an enthusiastic reception from others. Mark Diesendorf, vice-president of the Sustainable Energy Industries Council of Australia, described them as an "overrated voluntary scheme to assist business to make cost-effective reductions they should already be doing".

Following the government's controversial axing last May of its Energy Research and Development Corporation, which made grants for research on energy conservation and alternative energy, the new package does not include any grants for research. This has precipitated the resignation of Ros Taplin, director of Macquarie University's Climate Impact Centre in Sydney, saying there were no prospects for funding its research.

This week it was revealed that, in formulating a position that continues to generate controversy at home and abroad, Howard had not sought formal advice from Graeme Pearman, the leader of the country's largest programme of climate research at the Commonwealth Scientific and Industrial Research Organization.

PeterPockley

\section{Indian PM under fire on Edinburgh deal}

[LONDON] One of India's main environmentalist groups has criticized the prime minister for agreeing to make "significant reductions" to greenhouse gas emissions after the Kyoto conference.

The prime minister, I. K. Gujral, signed a declaration to that effect along with other Commonwealth leaders at summit meeting in Edinburgh at the end of October.

But Anil Agarwal, director of the Centre for Science and Environment in New Delhi, says Gujral should not have signed. Developing country participation is one of the US conditions to a greenhouse gas reduction treaty. Agarwal says that agreeing to the condition without asking for anything in return has left India and other developing countries with nothing to bargain with at Kyoto.

"The Indian prime minister may have jeopardized the position of the South even before the conference got under way," says Agarwal. "Gujral's endorsement also puts in jeopardy any demand to fix emissions on a per capita basis, rather than a per country basis."

Ehsan Masood

\section{Canada's line dents its green image}

[MONTREAL] Canada, the last of the G7 group of industrialized nations to announce its targets for next week's Kyoto meeting on global warming, has proposed a reduction of carbon dioxide emissions to 1990 levels by 2010. The proposal is in line with that of the United States - apparently confirming Canada's transformation from one of the world's politically 'greenest' countries to one of the most environmentally cautious.

Canada's target is less than that agreed five years ago at the signing of the climate convention in Rio, namely a return to emissions at 1990 levels by 2000 . Only Quebec has promised to adhere to the terms of the climate convention. The province has been more successful than others in reducing greenhouse gases, largely because of its reliance on hydroelectric power.

Canada's past support for environmentalist causes helped secure the country two high-profile prizes. Elizabeth Dowdeswell, former junior environment minister, was picked four years ago to head the United Nations Environment Programme. And two years ago Montreal was picked to host the secretariat of the UN biodiversity convention. Canada's shifting politics has coincided with the departure of Dowdeswell from the UNEP. There is also speculation that her replacement, the German Klaus Töpfer, may want all of the UN's environment agencies to move to Bonn. David Spurgeon \& Ehsan Masood

\section{Wirth hands over leadership of US delegation}

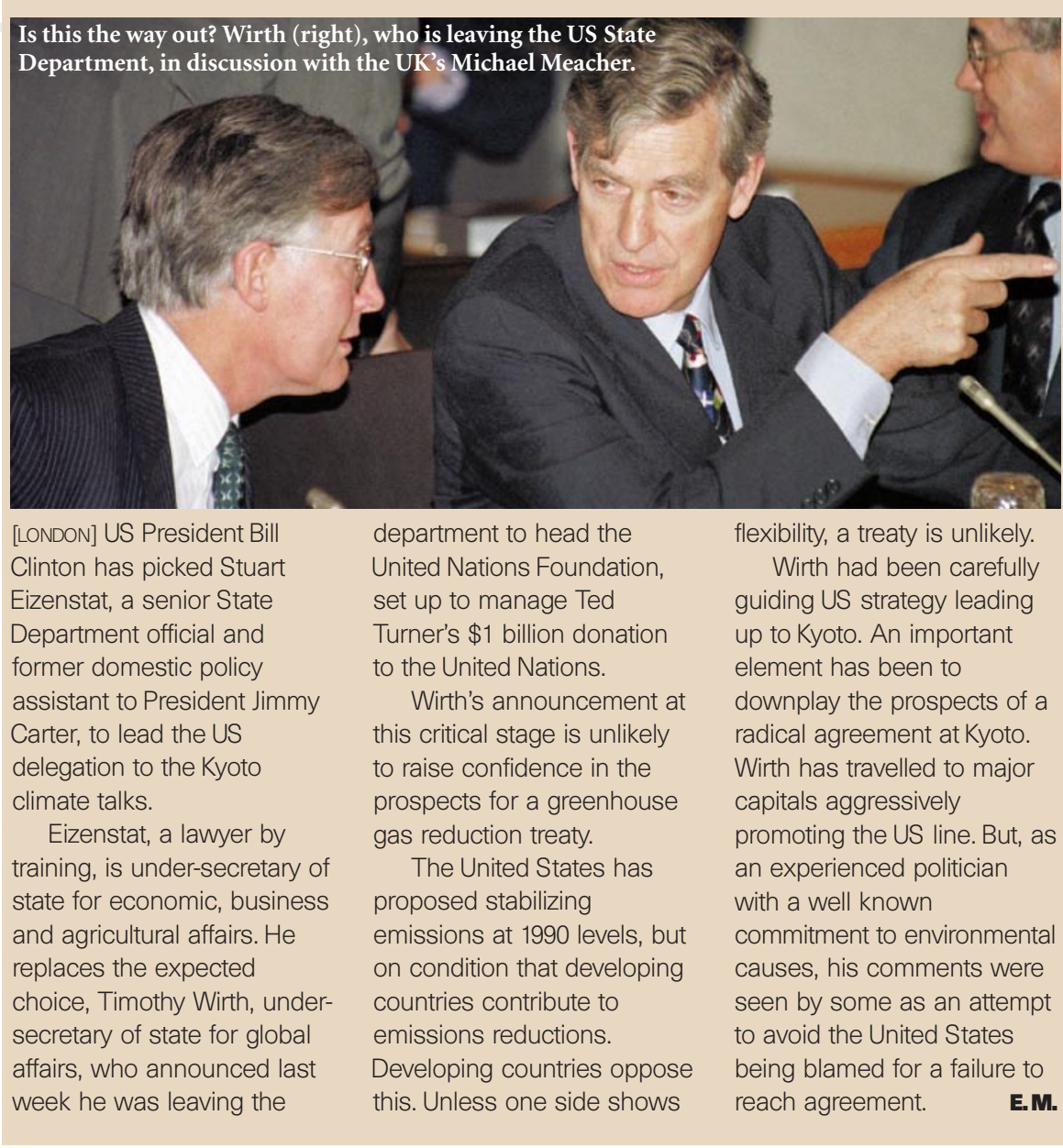

